\title{
Utrata i przywrócenie statusu miasta na prawach powiatu - na przykładzie Wałbrzycha
}

\# public tasks \# a city with country rights status \# municipal government \# administrative

law \# country

W artykule przedstawiono kształtowanie się procedury utraty i przywrócenia statusu miasta na prawach powiatu w prawie polskim. Autor stara się zwrócić uwagę na praktyczne aspekty zastosowania tych regulacji i potencjalne problemy. W tym celu posłużono się przykładem Wałbrzycha - jedynego miasta, które utraciło, a następnie odzyskało ten status. Artykuł wskazuje negatywne skutki związane z utratą praw powiatu dla dużego w skali kraju miasta oraz wyjaśnia, dlaczego powrót do poprzedniego stanu prawnego trwał w przypadku Wałbrzycha aż 10 lat.

The article presents the shaping of the procedure for the loss and restoration of the status of a city with country rights under Polish law. The author tries to draw attention to the practical aspects of the application of these regulations and the potential related problems. For this purpose, the example of Wałbrzych was used the only city that lost and then regained this status. The article shows the negative consequences related to the loss of country rights for a large city in the scale of Poland and explains why the return to the previous legal status lasted for 10 years in the case of Wałbrzych.

Miasto. Pamięć i Przyszłość 3/2 (2018) ISSN 2543-621X

\section{OPEN ACCESS}

Citation: Mika A., Utrata i przywrócenie statusu miasta na prawach powiatu - na przykładzie Wałbrzycha, "Miasto. Pamięć i Przyszłość", 3/2 (2018).

https://doi.org/10.26774/mpp.85

Editor: Jerzy Korczak

Received: October, 2018

Accepted: December, 2018

Published: December, 2018

Copyright: @ O Ośrodek „Pamięć i Przyszłość" This is an open access article distributed under the terms of the Creative Commons Attribution-ShareAlike Licence, which permits unrestricted use, distribution, and reproduction in any medium, provided the original author and source are credited, with indications if any changes are made. All derivative works must be licensed under the same licence.

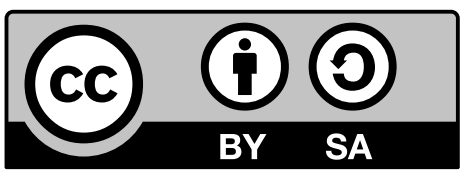


mgr Adam Mika - doktorant w Zakładzie Publicznego Prawa Gospodarczego Instytutu Nauk Administracyjnych na Wydziale Prawa, Administracji i Ekonomii Uniwersytetu Wrocławskiego

Miasto. Pamięć i Przyszłość 3/2 (2018) ISSN 2543-621X 


\section{Wstęp}

Rok 2018 r. jest rokiem obchodów dwudziestolecia utworzenia w Polsce samorządu powiatowego i województwa. Dwie dekady temu pojawiły się także miasta na prawach powiatu, a więc gminy obejmujące swoimi granicami jedynie ośrodki miejskie, którym przekazano także do realizacji zadania jednostek drugiego szczebla samorządu lokalnego'. Miast na prawach powiatu jest obecnie 66. Nie wszystkie z nich korzystały jednak z tego statusu przez cały okres ostatnich dwudziestu lat. Mowa w tym przypadku o Wałbrzychu², który najpierw był miastem na prawach powiatu, później status ten utracił, by następnie stoczyć prawdziwą batalię o jego przywrócenie. Miasto to stało się inspiracją dla autora niniejszej publikacji do prześledzenia kształtowania się w prawie polskim instytucji utraty i przywrócenia statusu miasta na prawach powiatu. Celem artykułu jest zbadanie genezy tych regulacji, zastosowania ich w praktyce oraz prawnych konsekwencji, które wywołują. Przedmiotem analizy będzie również

Miasto. Pamięć i Przyszłość 3/2 (2018) ISSN 2543-621X zdiagnozowanie potencjalnych mankamentów w tym zakresie. To wszystko powinno dać odpowiedź, dlaczego Wałbrzych jest dotychczas jedynym i prawdopodobnie ostatnim miastem, który utracił, a następnie odzyskał status miasta na prawach powiatu.

\section{Pierwotne uzyskanie przez Wałbrzych statusu miasta na prawach powiatu}

W 1999 r. weszła w życie reforma samorządowa, która doprowadziła do nowego podziału terytorialnego kraju. Liczba województw została istotnie ograniczona - wcześniej wynosiła ona 49, a po reformie została zredukowana do 16. Celem takiego rozwiązania było powiększenie tych jednostek, tak by były lepiej dostosowane do wykonywania zadań publicznych o charakterze

1. Zob. A. Wierzbicka, Domniemanie właściwości organów jednostek samorządu terytorialnego w realizacji zadań publicznych, "Samorząd Terytorialny" 2012, nr 12, s. 13; P. Lisowski, Utworzenie miasta na prawach powiatu w świetle regulacji o samorzadzie powiatowym, "Nowe Zeszyty Samorządowe" 2006, nr 1, s. 25; K. Podgórski, Nowy kształt organów wykonawczych gmin, "Samorząd Terytorialny" 2002, nr 10, s 5-6.

2. Warto pamiętać, że m.st. Warszawa uzyskała status miasta na prawach powiatu w dniu 27 października 2002 r., tj. od dnia wejścia w życie ustawy z dnia 15 marca 2002 r. o ustroju miasta stołecznego Warszawy (Dz.U. z 2015 r. poz. 1438). 
ponadregionalnym³. Na Dolnym Śląsku przed reformą istniały cztery województwa, tj. wrocławskie, wałbrzyskie, legnickie i jeleniogórskie. W wyniku wprowadzenia reformy zostały scalone w jedno województwo dolnośląskie ze stolicą we Wrocławiu. Zgodnie z art. 91 ustawy o samorządzie powiatowym4 prawa powiatu przysługiwały m.in. miastom, które przestały być siedzibami wojewodów. Miała to być dla nich rekompensata za utratę dawnej pozycji stolic wojewódzkich5. Wałbrzych należał do większości miast, które z tego rozwiązania skorzystały. Nie podążył zatem drogą, którą wybrały Piła, Sieradz i Ciechanów, i nie zrezygnował ze statusu miasta na prawach powiatu ${ }^{6}$.

W latach 2000-2001 zaczęły się pojawiać pierwsze oceny funkcjonowania zreformowanego samorządu terytorialnego. Swoje analizy przeprowadziły w tym czasie m.in. Sejm i Senat?

3. Por. uzasadnienie (druk nr 513) do projektu ustawy z dnia 24 lipca 1998 r. o wprowadzeniu zasadniczego trójstopniowego podziału terytorialnego państwa (Dz.U. Nr 96, poz. 603 z późn. zm.).

4. Ustawa z dnia 5 czerwca 1998 r. o samorządzie powiatowym (Dz.U. z 2018 r. poz. 995 z późn. zm.), dalej zwana w skrócie u.s.p.

5. P. Dobosz, [w:] Ustawa o samorzadzie powiatowym. Komentarz (art. 91), red. P. Chmielnicki, LEX/el.

6. Zgodnie z art. 91 u.s.p. istniała możliwość odstąpienia od nadania miastu praw powiatu na wniosek właściwej rady miejskiej.

7. Zob. uchwała Senatu Rzeczypospolitej Polskiej z dnia 11 stycznia 2001 r. w sprawie oceny nowego zasadniczego podziału terytorialnego państwa (M.P. z 2001 r. Nr 2, poz. 24) oraz uchwała Sejmu Rzeczypospolitej Polskiej z dnia 11 maja 2001 r. w sprawie oceny funkcjonowania zasadniczego podziału terytorialnego państwa (M.P. Nr 16, poz. 249).

8. Ocena nowego zasadniczego podziału terytorialnego państwa przyjęta przez Radę Ministrów w dniu 12 grudnia 2000 r. przygotowana przez Ministerstwo Spraw Wewnętrznych i Administracji, Warszawa, grudzień 2000 - druk nr 538 z 14 grudnia 2000 r., Senat RP, http://ww2.senat.pl [dostęp: 03.07.2018].

9. Ustawa z dnia 11 kwietnia 2001 r. o zmianie ustaw: o samorządzie gminnym, o samorządzie powiatowym, o samorządzie województwa, o administracji rządowej w województwie oraz o zmianie niektórych innych ustaw (Dz.U. Nr 45, poz. 497 z późn. zm.).
W dniu 12 grudnia 2000 r. Rada Ministrów przyjęła dokument pt. Ocena nowego zasadniczego podziału terytorialnego państwa ${ }^{8}$. Choć końcowe wnioski tam przedstawione wskazywały, że nowe rozwiązania co do zasady sprawdzają się, w raporcie tym nie zabrakło też uwag krytycznych. Autorzy dokumentu sygnalizowali znaczące dysproporcje w możliwości rozwoju większych miast i obszarów niezurbanizowanych. W szczególności podkreślano różnice potencjału powiatów, które swoją siedzibę miały w pobliskich miastach na prawach powiatu zamieszkałych przez nie więcej niż 150 tys. mieszkańców stanowiących centrum zawodowe i kulturalne okolic. Jako sposób rozwiązania tego problemu wskazano konieczność scalenia tych terytoriów. Co jednak istotne, w ówczesnym stanie prawnym brak było podstaw do przeprowadzenia takiego przedsięwzięcia. Ustawa w art. 3 ust. 2 w pierwotnym brzmieniu stanowiła jedynie, że Rada Ministrów może w drodze rozporządzenia tworzyć, łączyć, dzielić i znosić powiaty po zasięgnięciu zainteresowanych rad gmin, powiatów i sejmiku województwa. Zmiany w tym zakresie wprowadziła dopiero ustawa nowelizująca z dnia 11 kwietnia 2001 r.9. Po jej wejściu w życie w dniu 30 maja 2001 r., art. 3 ust 4 u.s.p. otrzymał nowe brzmienie, które rozszerzało rozumienie pojęcia „łączenia powiatów” także na sytuację połączenia miasta na prawach powiatu z powiatem mającym siedzibę władz w tym mieście. Skutkiem w tym przypadku było wygaśnięcie praw powiatu posiadanych dotychczas przez miasto. Ustawa nowelizująca doprecyzowywała

Miasto. Pamięć i Przyszłość 3/2 (2018) ISSN 2543-621X 
też procedurę połączenia omawianych jednostek samorządu terytorialnego. Proces scalania mógł być od teraz zainicjowany dwutorowo, tj. odgórnie z własnej inicjatywy Rady Ministrów albo oddolnie na wniosek zainteresowanej rady powiatu lub miasta. W obu przypadkach przewidziano obowiązkowe konsultacje z mieszkańcami i uzyskanie opinii powiatowych organów stanowiących. Celem tego rozwiązania było wzmocnienie w tych sprawach głosu lokalnej społeczności ${ }^{10}$. W przypadku inicjatywy oddolnej dodatkowo na temat połączenia powinny wypowiedzieć się rady okolicznych gmin i wojewoda. W tym wariancie wniosek należało złożyć do ministra właściwego do spraw administracji za pośrednictwem wojewody w terminie do 31 marca. Dokonane zmiany w podziale terytorialnym miałyby wchodzić w życie od 1 stycznia kolejnego roku.

\section{Utrata statusu miasta na prawach powiatu przez Wałbrzych}

W 2002 r. Wałbrzych rozpoczął starania o połączenie z Powiatem Wałbrzyskim. Pod koniec stycznia Rada Miejska podjęła uchwałę w sprawie przeprowadzenia konsultacji z mieszkańcami11. W kolejnym tygodniu wskazana uchwała została przesłana do Starosty Wałbrzyskiego z wnioskiem o zaopiniowanie. Inicjatywa Rady Miejskiej Wałbrzycha została następnie zakwestionowana przez Wojewodę Dolnośląskiego, który rozstrzygnięciami nadzorczymi z dni 8 i 21 lutego 2002 r. stwierdził częściową nieważność omawianej uchwały w zakresie

Miasto. Pamięć i Przyszłość 3/2 (2018) ISSN 2543-621X 145 powołania zespołów konsultacyjnych i ustalenia ich wyników ${ }^{12}$. Nie przeszkodziło to jednak w podjęciu próby zorganizowania konsultacji z mieszkańcami. Odbyły się one 6 marca 2002 r., choć trudno uznać ich wyniki za reprezentatywne. Wzięło w nich udział zaledwie o,6\%. mieszkańców. Wszystkie te działania doprowadziły ostatecznie do podjęcia przez Radę Miejską Wałbrzycha w dniu 20 marca 2002 r. kolejnej uchwały, tym razem dotyczącej złożenia do ministra spraw wewnętrznych i administracji wniosku o połączenie powiatu i miasta`3 ${ }^{13}$ Utrata statusu miasta na prawach powiatu nastąpiła w drodze rozporządzenia Rady Ministrów z dnia 25 czerwca 2002 r.14. Co jednak istotne, nie było to uwieńczenie procedury oddolnej rozpoczętej przez Wałbrzych. Scalenie miasta i powiatu wałbrzyskiego nastąpiło w wyniku inicjatywy

10. M. Brożek, Konstytucyjne podstawy partycypacji społecznej i formy jej realizacji w samorzadzie terytorialnym, „Przegląd Sejmowy” 2012, nr 5(112), s. 111. Więcej na ten temat: R. Marchaj, Samorzqdowe konsultacje społeczne, Warszawa 2016; J. Korczak, Dywersyfikacja terytorialna w działalności samorzadu terytorialnego, „Roczniki Nauk Prawnych" Tom XXV, 2015, nr 1, s. 129-130.

11. Uchwała nr XLV/27/2002 Rady Miejskiej Wałbrzycha z dnia 31 stycznia 2001 r., http://bip.um-walbrzych.dolnyslask.pl. [dostęp: 03.07.2018].

12. Por. wniosek Rady Miejskiej Wałbrzycha z dnia 12 grudnia 2002 r. o zbadanie zgodności §1 i §2 pkt 1 rozporządzenia Rady Ministrów z dnia z dnia 25 czerwca 2002 r. w sprawie połączenia miasta na prawach powiatu Wałbrzych z powiatem wałbrzyskim oraz ustalenia granic niektórych powiatów. (Dz. U. Nr 93, poz. 821) z art. 3 oraz art. $3 a$ ustawy z dnia 5 czerwca 1998 r. o samorządzie powiatowym (Dz. U. z 2001 r., Nr 142, poz.1592 z późn. zm.) z art. 5 Europejskiej Karty Samorządu Terytorialnego (Dz.U. z 1994 r. Nr 124, poz. 607) a także Konstytucją Rzeczypospolitej Polskiej, s. 3, http://bip.um-walbrzych.dolnyslask.pl. [dostęp: 03.07.2018], dalej zwany "wnioskiem Rady Miasta Wałbrzycha do Trybunału Konstytucyjnego".

13. Tamże.

14. Rozporządzenie Rady Ministrów z dnia 25 czerwca 2002 r. w sprawie połączenia miasta na prawach powiatu Wałbrzych z powiatem wałbrzyskim oraz ustalenia granic niektórych powiatów. (Dz. U. Nr 93, poz. 821). 
Własnej Rady Ministrów15. Konsekwencją wydania rozporządzenia było ustalenie nowych granic powiatu wałbrzyskiego, który od tej pory obejmował cztery gminy miejskie, tj. Boguszów-Gorce, Jedlinę-Zdrój, Szczawno-Zdrój oraz właśnie Wałbrzych.

Pewną ciekawostką jest fakt, że jeszcze przed wejściem rozporządzenia w życie, podjęto próbę zablokowania zmian, a jej inicjatorem była notabene Rada Miejska Wałbrzycha, która wcześniej aktywnie uczestniczyła w działaniach scaleniowych. Przyczyny tego stanu rzeczy upatrywać należy w wyborach samorządowych, które odbyły się jesienią 2002 roku6. W ich wyniku doszło do zmiany władz miejskich. Rada Miejska w dniu 30 grudnia 2002 r. podjęła uchwałę w sprawie wystąpienia do Trybunału Konstytucyjnego w celu zbadania zgodności rozporządzenia scaleniowego z regulacjami u.s.p. ${ }^{17}$ Wniosek wpłynął do Trybunału już w dniu 31 grudnia 2002 r. W uzasadnieniu wskazywano na niezachowanie obligatoryjnych elementów procedury łączenia powiatów. Głównym zarzutem było nieprzeprowadzenie konsultacji z mieszkańcami. Ponadto, zaniechano wystąpienia o opinie do organów stanowiących tych jednostek, które połączeniem miały zostać objęte. Rada Miejska

15. Zob. wniosek Rady Miasta Wałbrzycha do Trybunału Konstytucyjnego, s. 3.

16. Wybory samorządowe w Polsce w 2002 zostały przeprowadzone 27 października (I tura). II tura (ponowne głosowanie w wyborach wójtów, burmistrzów i prezydentów miast) odbyła się 10 listopada.

17. Uchwała Nr III/60/02 Rady Miejskiej Wałbrzycha z dnia 20 grudnia 2002 r., http://bip.um-walbrzych.dolnyslask.pl [dostęp: 03.07.2018].

18. Postanowienie Trybunału Konstytucyjnego z dnia 16 grudnia 2003 r., sygn. Tw 80/02, Legalis nr 63822.

19. Konstytucja Rzeczypospolitej Polskiej z dnia 2 kwietnia 1997 r. (Dz.U. Nr 78 poz. 483 z późn. zm.).
Wałbrzycha jako inicjator wniosku podkreślała, że u.s.p. nie dawała Radzie Ministrów możliwości odstąpienie od przeprowadzenia poszczególnych etapów procedury scaleniowej. Miało to świadczyć o istotnej wadliwości rozporządzenia. Trybunał Konstytucyjny zajął się sprawą po roku. Wcześniej Rada Miejska wzywana była do uzupełnienia braku formalnego wniosku polegającego na niewskazaniu konkretnego przepisu, z którym zaskarżone rozporządzenie miałoby być sprzeczne. Ostatecznie wnioskodawca wskazał w tym zakresie na art. 92 u.s.p. Postanowieniem z dnia 16 grudnia 2003 r. Trybunał Konstytucyjny odmówił nadania sprawie dalszego biegu ${ }^{18}$. W uzasadnieniu wskazał, że Rada Miejska Wałbrzycha, jako organ stanowiący gminy na podstawie art. 192 ust 2 Konstytucji19, ma jedynie ograniczoną kompetencję do zaskarżania aktów normatywnych. Przedmiotem jej wniosku mogą być zatem tylko takie przepisy, które dotyczą spraw objętych zakresem działania wnioskodawcy. Miasta na prawach powiatu to gminy, które mają realizować również zadania publiczne należące do powiatu. Trybunał zaznaczył, że powierzenie wykonywania kompetencji organów innego szczebla samorządu terytorialnego leży jedynie w gestii ustawodawcy. Rada Miejska nie może kwestionować przepisów znoszących zadania i kompetencje o charakterze powiatowym, przyznane wcześniej gminie miejskiej na podstawie szczególnych regulacji. Nie sposób traktować art. 92 u.s.p. jako przepisu dotyczącego merytorycznych spraw objętych działaniem wnioskodawcy. Wniosek należało

Miasto. Pamięć i Przyszłość 3/2 (2018) ISSN 2543-621X 
zatem odrzucić z przyczyn formalnych. Przesądzone tym samym zostało, że Wałbrzych od 1 stycznia 2003 r. został połączony z powiatem wałbrzyskim i stał się największym miastem w Polsce, któremu nie przysługiwał status miasta na prawach powiatu.

\section{Skutki utraty statusu miasta na prawach powiatu}

Połączenie Wałbrzycha z Powiatem Wałbrzyskim doprowadziło do wielu trudności w funkcjonowaniu miasta. Przedstawienie ich wszystkich wykracza poza ramy niniejszego artykułu, dlatego też omówione zostaną tylko wybrane problemy. W pierwszej kolejności wskazać należy na rozproszenie kompetencji między prezydentem miasta a starostą ${ }^{20}$. Nabierało to istotnego znaczenia np. w przypadku zarządu drogami publicznymi i podziału na drogi gminne i powiatowe, które przebiegały przez miasto. Za pierwsze odpowiedzialność spoczywała nadal na Prezydencie Miasta, za drugie - przejął ją Starosta Wałbrzyski. Od momentu scalenia Wałbrzycha z okalającym go powiatem dużo trudniej zatem było zaplanować remont lub przebudowę ciągów komunikacyjnych. Każda większa inwestycja wymagała wspólnych uzgodnień obu jednostek samorządu terytorialnego co do sensu jej przeprowadzenia, skoordynowania harmonogramu prac oraz zabezpieczenia środków pieniężnych w dwóch różnych budżetach.

Innym problemem okazało się wydłużenie niektórych procedur administracyjnych. Pojawiły się dodatkowe obligatoryjne zawiadomienia,

Miasto. Pamięć i Przyszłość 3/2 (2018) ISSN 2543-621X konsultacje, uzgodnienia między Prezydentem Miasta a Starostą ${ }^{21}$. Powodowało to dłuższe oczekiwanie na wydanie decyzji administracyjnej lub aktu prawa miejscowego. Ponadto, połączenie miasta i powiatu wiązało się z koniecznymi zmianami organizacyjnymi, co dla części mieszkańców było niezrozumiałe. Przykładem może być załatwienie wszystkich formalności związanych z rozpoczęciem budowy domu. Do tej pory uzyskanie decyzji o warunkach zabudowy, a następnie pozwolenia na budowę odbywało się w Urzędzie Miejskim. Po zmianach, organem właściwym do wydania pozwolenia na budowę w obrębie Wałbrzycha stał się Starosta Wałbrzyski. Wszystkie dokumenty niezbędne do wszczęcia postępowania w tej sprawie składać zatem należało w Starostwie Powiatowym a nie Urzędzie Miejskim.

Potencjalnie spornym punktem między Prezydentem Miasta a Starostą stały się też działające w Wałbrzychu zespoły szkół gimnazjalnych i ponadgimnazjalnych, którymi kierował jeden dyrektor ${ }^{22}$. Szkolnictwo obejmujące szkołę podstawową oraz gimnazjum należało do zadań gminy. Z kolei prowadzenie liceum oraz innych placówek oświaty na poziomie ponadgimnazjalnym ustawa powierzyła samorządowi powiatowemu. Zaistniała zatem konieczność,

20. Szerzej na temat kompetencji prezydenta miasta w mieście na prawach powiatu: A. Wierzbicka, [w:] Ustawa o samorzadzie powiatowym. Komentarz (art. 92), red. B. Dolnicki, LEX/el.

21. Przykładem może tutaj być art. 17 pkt 6 lit. a tiret ósme ustawy z dnia 27 marca 2003 r. o planowaniu i zagospodarowaniu przestrzennym (Dz. U. z 2017 r. poz. 1073, 1566), na podstawie którego wójt (burmistrz, prezydent miasta) po podjęciu przez radę gminy uchwały o przystąpieniu do sporządzania planu miejscowego występuje do starosty opinie o projekcie planu.

22. Więcej na ten temat F. Żurakowski, Szkolnictwo w Wałbrzychu w latach 1945-2015. Instytucje, ludzie, idee, [w:] Wałbrzyskie Szkice, red. S. Bielawska, Wałbrzych 2015, s. 267 i n. 
by Starosta oraz Prezydent Miasta wypracowali ramy współpracy również w tej dziedzinie.

Połączenie Wałbrzycha i Powiatu Wałbrzyskiego miało również negatywne konsekwencje dla finansów miasta i planowania wydatków. Brak realizacji powiatowych zadań publicznych był równoznaczny z koniecznością okrojenia jego budżetu. Miało to istotny wpływ na zdolność kredytową i możliwość spłaty dotychczasowych zobowiązań. Szybko okazało się też, że Wałbrzych, nie będąc już miastem na prawach powiatu, nie może starać się o dofinansowanie ze środków unijnych, które zostały przewidziane jedynie dla gmin o takim statusie. Był to spory cios, tym bardziej że środki te walnie przyczyniły się do poprawy ogólnej infrastruktury. Dzięki nim m.in. w Legnicy zbudowano obwodnicę²3.

Nie można również zapominać o negatywnych konsekwencjach wizerunkowych dla Wałbrzycha24. Była stolica województwa, drugie miasto pod względem ludności na Dolnym Śląsku zostało w ciągu 4 lat zdegradowane do

23. Chodzi m.in. o projekt współfinansowany przez Unię Europejską ze środków Europejskiego Funduszu Rozwoju Regionalnego w ramach Sektorowego Programu Operacyjnego Transport „Budowa Obwodnicy Zachodniej Legnicy - Etap ID - odcinek od ul. Nowodworskiej do autostrady A4".

24. Więcej temat w zakresie utraty statusu miasta wojewódzkiego: D. Krysiński, Wszystko, co złe, to reforma. O utracie statusu miasta wojewódzkiego w dyskursie Kaliszan, "Przegląd Socjologiczny” 2013, z. 62 , s. 37.

25. Przykładem może być poparcie Wałbrzycha dla apelu prezydenta Inowrocławia "Nadajcie naszym miastom taki sam status, jaki mają inne miasta prezydenckie" z 2008 r., http://www.e-samorzad.pl [dostęp: 03.07.2018].

26. M. Karciarz, A. Kudra, Dopuszczalność nadania statusu miasta na prawach powiatu w świetle obowiq̨ujacych przepisów prawa, "Samorząd Terytorialny" 2015, nr 10, s.73-75.

27. Ustawa z dnia 23 stycznia 2009 r. o zmianie niektórych ustaw w związku ze zmianami w organizacji i podziale zadań administracji publicznej w województwie (Dz. U. Nr 92, poz. 753, Nr 99 z późn. zm.). poziomu zwykłej gminy miejskiej. To wszystko doprowadziło do tego, że już po kilku latach połączenie Wałbrzycha z Powiatem Wałbrzyskim było powszechnie krytykowane.

\section{Przywrócenie statusu miasta na prawach powiatu}

Brak możliwości rozwoju na poziomie zbliżonym do miast o podobnym potencjale, spowodował podejmowanie przez Wałbrzych licznych inicjatyw zmierzających do odzyskania statusu miasta na prawach powiatu25. Problemem okazały się jednak obowiązujące regulacje prawne. Ustawa nowelizująca u.s.p. z 2001 r. wprowadziła co prawda podstawy do połączenia miasta na prawach powiatu z powiatem, którego władze miały siedzibę w tym mieście, nie zawierała jednak unormowań co do procedury odwrotnej ${ }^{26}$. Treść art. 3 ust 5 u.s.p., regulującego kwestię szczególnych przypadków dzielenia powiatów, obejmowała wówczas swoją hipotezą tylko dwie sytuacje. Po pierwsze, mogło to nastąpić w razie wyłączenia gminy (kilku gmin) z jednego powiatu celem jej (ich) jednoczesnego włączenia do innego powiatu. Po drugie, podział powiatu mógł także nastąpić poprzez wydzielenie gmin i utworzenia z nich odrębnej jednostki samorządu terytorialnego drugiego stopnia. Żadna z tych regulacji nie dotyczyła zatem kazusu Wałbrzycha. Zachodziła więc konieczność uchwalenia kolejnej nowelizacji u.s.p.

Przełomem w tej kwestii okazała się tzw. ustawa kompetencyjna uchwalona przez Sejm w 2009 r. ${ }^{27}$. Była to nowela różnych

Miasto. Pamięć i Przyszłość 3/2 (2018) ISSN 2543-621X 
aktów prawnych mająca za zadanie poprawę funkcjonowania państwa w określonych dziedzinach. W art. 14 wprowadzała ona zmianę w u.s.p., dodając w jej art. 5 ust. 3 pkt 3, dzięki któremu podział powiatu mógł nastąpić także w razie przywrócenia statusu miasta na prawach powiatu miastu, które w trybie ust. 4 zostało połączone z powiatem mającym siedzibę władz w tym mieście. Sposób redakcji przepisu nie pozostawiał wątpliwości, dla której miejscowości został on wprowadzony ${ }^{28}$. Ustawa kompetencyjna została przekazana do podpisu Prezydentowi RP w dniu 26 stycznia 2009 r., w kolejnym miesiącu została jednak przez niego skierowana do Trybunału Konstytucyjnego. Co istotne, Prezydent nie kwestionował konstytucyjności zmian w u.s.p. ${ }^{29}$, niemniej jednak, do momentu rozpoznania sprawy przez Trybunał, cała ustawa kompetencyjna nie mogła wejść w życie. Ostatecznie orzeczono, że proponowane zmiany są zgodne z Konstytucją. Od 1 sierpnia 2009 r. w polskim porządku prawnym obowiązywała zatem regulacja pozwalająca Wałbrzychowi starać się o przywrócenie dawnego statusu. Najwcześniej mogło to się stać z dniem 1 stycznia 2011 r. Przy podziale powiatów przewidziana została bowiem podobna procedura jak przy ich łączeniu. W tym przypadku również inicjujący postępowanie mogła złożyć do ministra ds. administracji za pośrednictwem wojewody rada zainteresowanej gminy. Termin graniczny na podjęcie tej czynności został wyznaczony na 31 marca. Rozporządzenie Rady Ministrów przewidujące

Miasto. Pamięć i Przyszłość 3/2 (2018) ISSN 2543-621X zmiany terytorialne wchodziłoby w życie od kolejnego roku. Podobnie jak łączenie powiatów, także ich podział wymagał uprzednich konsultacji z mieszkańcami i wyrażenia opinii przez jednostki samorządu terytorialnego znajdujące się w najbliższym sąsiedztwie.

Inaczej niż powszechnie oczekiwano, Wałbrzych nie złożył wniosku o podział powiatu wałbrzyskiego już w pierwszym możliwym terminie. Dużą przeszkodą do odzyskania statusu miasta na prawach powiatu okazały się sprawy finansowe, a dokładnie przejęcie odpowiedzialności za dotychczasowe zadłużenie Powiatu. W żaden sposób kwestia ta nie została prawnie uregulowana. Oznaczało to konieczność wypracowania porozumienia między miastem a powiatem, co nie było sprawą prostą. Impas został przerwany dopiero w 2011 r. Wówczas Prezydent Wałbrzycha złożył publiczną deklarację o przejęciu przez miasto całości zadłużenia powiatu wałbrzyskiego ${ }^{30}$. Ostatecznie nastąpito to w wyniku kilku umów cywilnoprawnych o przejęciu długu zawartych między Gminą Wałbrzych a bankami - wierzycielami powiatu na

28. W uzasadnieniu do rządowego projektu ustawy kompetencyjnej (druk nr 1073) wprost wskazywano, że zmiany w ustawie o samorządzie powiatowym ograniczają się do poszerzenia definicji dzielenia powiatów o przywrócenie statusu miasta na prawach powiatu miastu, które zostało połączone z powiatem mającym siedzibę władz w tym mieście. Zmiana ta jest związana z przewidywanym przywróceniem takiego statusu Wałbrzychowi, http://orka. sejm.gov.pl. [dostęp: 03.07.2018].

29. Zakwestionowane zostały zmiany przewidziane w art. 21 ustawy kompetencyjnej dotyczących zmian w ustawie z dnia 16 kwietnia 2004 r. o ochronie przyrody (Dz.U. Nr 92, poz. 880 z późn. $\mathrm{zm}$.).

30. Zob. odpowiedź podsekretarza stanu w Ministerstwie Administracji i Cyfryzacji na zapytanie nr 3036 w sprawie dalszego funkcjonowania od dnia 1 stycznia 2013 r. Rady Powiatu Wałbrzyskiego oraz Zarządu Powiatu Wałbrzyskiego, a także sposobu przejęcia długu powiatu przez miasto Wałbrzych, http://www.sejm. gov.pl. [dostęp: 03.07.2018]. 
łączną kwotę 34683 362,00 zł³1. W ten sposób otworzyła się droga do podjęcia pozostałych obligatoryjnych czynności niezbędnych do zakończenia procedury podziałowej. W okresie 2011-2012 przeprowadzono konsultacje z mieszkańcami, opinie wyrażały również gminy tworzące powiat wałbrzyskich. Warto zauważyć, że z dziewięciu takich gmin tylko dwie poparły starania Wałbrzycha, aż pięć było przeciw, a jedna wstrzymała się od głosu². Przeciwko temu rozwiązaniu głosowała również Rada Powiatu Wałbrzyskiego. Nie przeszkodziło to jednak Ministrowi Administracji i Cyfryzacji wszcząć na wniosek Rady Miasta Wałbrzycha postępowania podziałowego. Ważnym argumentem przemawiającym za stanowiskiem miasta była pozytywna opinia wyrażona przez Regionalną Izbę Obrachunkową we Wrocławiu w kwestii skutków finansowych ${ }^{33}$. Nie stwierdzono w niej przeciwskazań do proponowanych zmian terytorialnych. Przywrócenie Wałbrzychowi statusu miasta na prawach powiatu nastąpiło w drodze rozporządzenia Rady Ministrów z dnia 10 lipca 2012 r.34. Rozporządzenie zaczęło obowiązywać od 1 stycznia 2013 r., a więc równo po 10 latach od pozbawienia Wałbrzycha praw powiatu.

31. Tamże.

32. Za opowiedziały się Wałbrzych, Jedlina-Zdrój oraz Walim; przeciw były Czarny Bór, Głuszyca, Mieroszów, Boguszów-Gorce i Szczawno-Zdrój; gminą, która wstrzymała się od głosowania były Stare Bogaczowice.

33. Chodzi o opinię prezesa Regionalnej Izby Obrachunkowej we Wrocławiu w piśmie z dnia 18 stycznia 2012 r. w kwestii skutków finansowych ewentualnego wyłączenia miasta Wałbrzycha z powiatu i przywrócenia mu statusu miasta na prawach powiatu, http://bip.um-walbrzych.dolnyslask.pl.

34. Rozporządzenie Rady Ministrów z dnia 10 lipca 2012 r. w sprawie przywrócenia miastu Wałbrzych statusu miasta na prawach powiatu oraz ustalenia granic powiatu wałbrzyskiego (Dz.U. poz. 853).

35. Zob. art. 4 ust. 1 u.s.p.

\section{Skutki przywrócenia statusu miasta na prawach powiatu}

W wyniku wydzielenia z powiatu wałbrzyskiego i przywrócenia statusu miasta na prawach powiatu Wałbrzych ponownie stał się odpowiedzialny za realizację zadań publicznych przypisanych powiatowej jednostce samorządu terytorialnego. Dotyczyło to spraw z zakresu m.in. utrzymania dróg, szkolnictwa ponadgimnazjalnego, zabezpieczenia socjalnego, nadzoru budowlanego, promocji zatrudnienia czy też gospodarki nieruchomościami Skarbu Państwa znajdujących się na terenie miasta35. Sposób przejęcia tych zadań od Powiatu Wałbrzyskiego nie został jednak uregulowany normatywnie. Podobnie zatem jak w przypadku odpowiedzialności za zadłużenie, także tę kwestię pozostawiono do uzgodnienia między zainteresowanymi jednostkami samorządu terytorialnego. Po raz kolejny okazało się, że osiągnięcie kompromisu nie we wszystkich sprawach jest możliwe z uwagi na sprzeczność interesów miasta i powiatu.

Główną kością niezgody pozostawała kwestia prowadzenia urzędu pracy. Zarówno miasto, jak i powiat dążyły do przejęcia realizacji tego zadania. Brak porozumienia między jednostkami oznaczałby konieczność organizowania dwóch odrębnych urzędów pracy. Rodziłoby to uzasadnione pytanie o celowość takiego rozwiązania, gdyż zdecydowaną większość miejsc pracy w okolicy i tak generował Wałbrzych. Ostatecznie Miasto i Powiat podpisały porozumienie, w wyniku którego ustalono, że urząd pracy nadal prowadzony będzie przez Powiat

Miasto. Pamięć i Przyszłość 3/2 (2018) ISSN 2543-621X 
Wałbrzyski, a Wałbrzych przeznaczał będzie na ten cel dotacje celowe ${ }^{36}$. Porozumienie jest cyklicznie odnawiane do tej pory.

Innym problemem okazało się prowadzenie wydziału komunikacji. Zarówno powiat, jak i miasto wyrażały chęć wykonywania zadań publicznych także w tym zakresie. Mimo licznych rozmów, porozumienie nie zostało osiągnięte. Po przywróceniu Wałbrzychowi praw powiatu, utworzono więc odrębne komórki organizacyjne w ratuszu i starostwie. Prowadziło to do kuriozalnych sytuacji. Mieszkańcy Wałbrzycha, którzy rejestrowali swoje pojazdy przed 2003 r., nadal widnieli w bazie Wydziału Komunikacji Starostwa Powiatowego, choć podlegali już pod Biuro Komunikacyjne Urzędu Miejskiego. W przypadku załatwienia prostej sprawy, np. uzyskania nowej tablicy rejestracyjnej, konieczne było zatem przerejestrowanie samochodu pomiędzy urzędami. Odbywało się to tylko na wniosek, dodatkowo wiązało się z dużo większymi kosztami i pochłaniało znacznie więcej czasu. Czarę goryczy przelał fakt, że w pierwszym okresie funkcjonowania dwóch odrębnych komórek organizacyjnych mieściły się one w jednym budynku w sąsiednich pomieszczeniach, a petenci byli przez urzędników odsyłani od okienka do okienka37.

Kolejną nierozwiązaną normatywnie kwestią było przekazanie nieruchomości. W związku z tym, że miasto przejęło liczne zadania, których wcześniej nie wykonywało, konieczne okazało się zdobycie większej powierzchni biurowej.

Miasto. Pamięći Przyszłość 3/2 (2018) ISSN 2543-621X 151
Z kolei po zmianach administracyjnych Powiat Wałbrzyski nie potrzebował już tak rozbudowanego zaplecza organizacyjnego, jakie posiadał do tej pory. Naturalną konsekwencją tego stanu rzeczy było zatem przekazanie części nieruchomości Wałbrzychowi. Wymagało to jednak odrębnego porozumienia w zakresie ustalenia chociażby konkretnych lokalizacji i charakteru udostępnienia.

Ważnym skutkiem przywrócenia Wałbrzychowi statusu miasta na prawach powiatu była konieczność ustanowienia zarządu komisarycznego w Powiecie Wałbrzyskim. Wynikało to z ustalenia jego nowych granic terytorialnych. Jak stanowił ówcześnie obowiązujący art. 197 ust. 1 pkt 1 Ordynacji wyborczej do rad gmin, rad powiatów i sejmików województw ${ }^{38}$, zmiany w obrębie okręgów wyborczych z mocy prawa powodowały wygaśnięcie mandatu radnego. Z kolei art. 197 ust. 5 tej ustawy przewidywał, że jeżeli modyfikacje granic doprowadzą do zmniejszenia się liczby radnych poniżej 3/5 ustawowej ich liczby, rada jednostki zostaje z mocy prawa rozwiązana. Tak też było w tym przypadku. Od 1 stycznia 2013 r. nastąpiło skrócenie kadencji organu stanowionego powiatu wałbrzyskiego oraz jego zarządu.

36. Porozumienie NR OR.031.10.2013 z dnia 25 kwietnia 2013 r. pomiędzy Powiatem Wałbrzyskim a Gminą Wałbrzych w sprawie realizacji zadań z zakresu ustawy o promocji zatrudnienia i instytucjach rynku pracy (Dz. Urz. Woj. Doln. z 2013 r. poz. 4415). Porozumienie to doktrynalnie można zakwalifikować jako tzw. porozumienie horyzontalne.Więcej na ten temat: J. Korczak, O nieporozumieniach wokół porozumień w administracji publicznej, "Samorząd Terytorialny" 2009, nr 6, s. 33-38.

37. Zob. A. Szałkowski, Właściciele pojazdów z Wałbrzycha maja kłopot, http://walbrzych.naszemiasto.pl [dostęp: 03.07.2018].

38. Ustawa z dnia 16 lipca 1998 r. Ordynacja wyborcza do rad gmin, rad powiatów i sejmików województw (Dz.U. z 2010 r. Nr 176, poz. 1190). 


\section{Podsumowanie i wnioski}

Instytucja połączenia miasta na prawach powiatu z powiatem, którego siedziba w tym mieście się znajduje, nie była początkowo przewidziana w polskim prawie. Nowelizacja, która ją wprowadzała, skupiała się głównie na procedurze, nie na skutkach scalenia tych dwóch jednostek samorządu terytorialnego. Na przykładzie Wałbrzycha widać, że rozwiązanie to doprowadziło do wielu niespodziewanych perturbacji. Dekoncentracja kompetencji między starostą a prezydentem miasta groziła paraliżem decyzyjnym przy ważniejszych sprawach dla miasta. Hamulcem rozwojowym była również bariera przy ubieganiu się o środki unijne.

Negatywnie ocenić także należy brak możliwości skontrolowania zachowania wszystkich obligatoryjnych elementów procedury scaleniowej przez Radę Ministrów. Zwrócił na to uwagę Trybunał Konstytucyjny, nie rozpoznając merytorycznie wniosku organu stanowiącego gminy o zbadanie konstytucyjności wydanego rozporządzenia. Nie da się ukryć, że czyni to wszystkie obowiązki konsultacyjne z mieszkańcami oraz najbliższymi jednostkami samorządu terytorialnymi czysto fasadowymi.

Po latach okazało się, że połączenie zamiast stać się bodźcem dla powiatu i tworzących go mniejszych miasteczek i wsi, powoduje przede wszystkim negatywne konsekwencje dla byłego miasta na prawach powiatu. Mając to na uwadze, ustawodawca wprowadził regulacje pozwalające na odwrócenie skutków połączenia. Po raz kolejny jednak było to działanie ad hoc i nieregulujące sprawy kompleksowo. Zabrakło przepisów szczegółowych dotyczących m.in. spraw finansowych w zakresie rozłożenia zadłużenia powiatu, przejęcia pracowników i nieruchomości. Wszystkie te konfliktogenne kwestie pozostawiono zainteresowanym jednostkom samorządu terytorialnego do uzgodnienia w drodze odrębnych porozumień.

Działanie ustawodawcy należy ocenić negatywnie, nie zauważono bowiem, że powiat i miasto mogą przejawiać tutaj antagonistyczne interesy. Nie inaczej było w przypadku Powiatu Wałbrzyskiego i Wałbrzycha. Powiat do ostatniej chwili próbował zatrzymać dążenie miasta do odzyskania dawnego statusu. W wyniku podziału tracił m.in istotną część finansowania. Równie ważne było także wygaszenie mandatów radnych i członków zarządu. Nie sposób zatem dziwić się, że Powiat nie przejawiał zainteresowania wydzieleniem Wałbrzycha. Istotnie utrudniło to osiąganie jakichkolwiek porozumień, a co za tym idzie - przeprowadzenie całej procedury. Mając to wszystko na uwadze, wysoce wątpliwe jest, by procedury prowadzące do utraty i przywrócenia statusu miasta na prawach powiatu znalazły jeszcze kiedyś zastosowanie do jakiegokolwiek innego miasta w Polsce.

Miasto. Pamięć i Przyszłość 3/2 (2018) ISSN 2543-621X 


\section{Literatura:}

- M. Brożek, Konstytucyjne podstawy partycypacji społecznej i formy jej realizacji w samorzadzie terytorialnym, "Przegląd Sejmowy” 2012, nr 5(112).

- P. Dobosz, [w:] Ustawa o samorzadzie powiatowym. Komentarz (art. 91), red. P. Chmielnicki, LEX/el.

- M. Karciarz, A. Kudra, Dopuszczalność nadania statusu miasta na prawach powiatu w świetle obowiqzujących przepisów prawa, „Samorząd Terytorialny” 2015 nr 10.

- J. Korczak, Dywersyfikacja Terytorialna w działalności samorzadu terytorialnego, „Roczniki nauk prawnych” Tom XXV, 2015, nr 1.

- J. Korczak, O nieporozumieniach wokół porozumień w administracji publicznej, "Samorząd Terytorialny” 2009, nr 6.

- D. Krysiński, Wszystko, co zte, to reforma. O utracie statusu miasta wojewódzkiego w dyskursie Kaliszan, „Przegląd Socjologiczny” 2013, z. 62.
- P. Lisowski, Utworzenie miasta na prawach powiatu w świetle regulacji o samorzadzie powiatowym, "Nowe Zeszyty Samorządowe" 2006, nr 1.

- R. Marchaj, Samorządowe konsultacje społeczne, Warszawa 2016.

- K. Podgórski, Nowy kształt organów wykonawczych gmin, "Samorząd Terytorialny” 2002, nr 10.

- A. Wierzbicka, Domniemanie właściwości organów jednostek samorzadu terytorialnego w realizacji zadań publicznych, "Samorząd Terytorialny” 2012, nr 12.

- A. Wierzbicka, [w:] Ustawa o samorzadzie powiatowym. Komentarz (art. 92), red. B. Dolnicki, LEX/el.

- F. Żurakowski, Szkolnictwo w Watbrzychu w latach 1945-2015. Instytucje, ludzie, idee, [w:] Wałbrzyskie Szkice, red. S. Bielawska, Wałbrzych 2015. 